\title{
Procedural Reality in Corsica under the Rule of the Banco di San Giorgio after 1453
}

The colonization of Corsica (1453-1562) by the Genoese Banco di San Giorgio, a private financial institution with public powers, aimed at restoring law and order and installing a modern administration. However, the economic exploitation of the Isle was the ultimate goal of the capital investors of the Banco. The controversy about the nature and impact of the Banco's governance on the Isle could disclose a particular stadium in the colonial and capitalistic expansion of the West. The attempt to establish a social contract between the Genoese administrators and the Corsican forces of opposition was revelatory. More specifically, we will discuss the internal processes of democratization in a fragmented Corsican society within an external colonial framework of oppressors which were themselves affected by sociopolitical struggles in the Republic of Genoa. In this way we will try to show how the interaction between the popular movement in Corsica and the new administrative model of the Banco di San Giorgio signified fascinating transformations in political philosophy and legal history. However the sad conclusion is that the struggle for equality was equivalent with a bloody disaster.

\section{Introduction}

The purpose of the paper is to present some general observations about the procedural reality in Corsica under the colonial governance of the Genoese Banco di San Giorgio in the $15^{\text {th }}$ and $16^{\text {th }}$ centuries. This is framework of my PhD thesis which did only very recently get started. It will disclose the case law of the sovereign jurisdiction of the Banco over Corsica between 1453 and 1562, with a focus on civil rights and liberties. These documents ${ }^{1}$ are to be found in the Archivio di Stato di Genova ${ }^{2}$ and comes under the administrative unit of the Cancelleria. ${ }^{3}$ For today, I have tried to structure the topic in a gradual way. First, I will define the particular place and role of Corsica in Mediterranean and

\footnotetext{
${ }^{1}$ FeLLoni, L'Archivio della Casa di San Giorgio.

${ }^{2}$ FELLONI, Inventario dell'Archivio 1.

${ }^{3}$ Chiaudano, Costamagna, L'archivio storico del Banco di San Giorgio 115; GraZIANA, Visti ghe Corse.
}

European history. Second, the particular features of the Banco di San Giorgio in financial and colonial history will be described. Against this background, I will zoom into the legal changes and developments from 1358 onwards with special attention to its relationship with political ideology and historical events.

Indeed, my broader viewpoint is the intertwinement of procedural conceptions and political ideology and philosophy. Therefore, the core legal historian problem tackles the political deliberation of the conflicting powers in Corsican society as a determinative force for the procedure of the colonial authority.

\section{What is wrong with Corsica?}

United in diversity, the current European integration process consists of several violent separatist regions, on the basis of legal, political and 
economic grounds. ${ }^{4}$ The Isle of Corsica is one of them.

Le problème corse 5 could be symbolized by three striking questions: Why is "Un mauvais fusil vaut mieux qu'un bon juge." 6 a Corsican aphorism? Why is political violence, with bombing attacks, murders and fraudulent clientelism, ${ }^{7}$ seemingly ineradicable? ${ }^{8}$ Why was, when a new project for the economic disclosure of the Corsican South was proposed by the European Commission, everyone sneering: "Is it an airport for goats?"

Evidently, a look back towards the French occupation of the Isle since 1768 could explain more why Corsica is for already such a long time the poorest and most unstable department of France. But there are good reasons to dive even further into the period of Genoese dominance of the Isle. ${ }^{10}$

Namely, the Genoese Banco di San Giorgio played a crucial role in the fascinating coincidence of Corsican and European history that occurred in the fatidic year $1453 .{ }^{11}$ On the one hand, major legal, political and economic transformations gained momentum by the collapse of the Eastern Roman Empire in the mid-15 $5^{\text {th }}$ century. They wove the patterns of early modern European history with a significant outcome in the Europe of nation states, three centuries later. ${ }^{12}$ On the other hand, the sovereign rights over Corsica were transferred from the financially exhausted Republic of Genoa towards the Banco di San Giorgio as a result of the fall of Constantinople.

\footnotetext{
${ }^{4}$ For example: Northern Ireland, Scotland, Basque Country, Cyprus, ...

${ }^{5}$ D'OrAZIO, Une île de violence 14.

${ }^{6}$ Delahaye, La Corse.

${ }^{7}$ Compare with the political plug money in Greece known as fakelaki or little envelopes.

${ }^{8}$ BBC News, Life for Corsica prefect murder.

${ }^{9}$ Regional policy European Union, The airport for goats.

${ }^{10}$ Global period from 1284 till 1768.

${ }^{11}$ VERGE-FRANCHESI, La Corse enjeu géostratégique.

${ }^{12}$ Arrighi, JeHASSE, Histoire de la Corse 239.
}

That is precisely why it is very remarkable and regretful that we know almost nothing about the Banco's role in colonial (legal) history and its influence on Corsica (1453-1562) in particular.

\section{What is special about the Banco di San Giorgio?}

In 1407 the Casa delle compere e dei banchi di San Giorgio was established in the Ligurian port of Genoa as a re-arrangement of the rights of creditors, mostly aristocratic families, in order to consolidate the state debt. ${ }^{13}$ The gradual political and financial dismantlement of the Serenissima ${ }^{14}$ meant that the Banco di San Giorgio became, according to Machiavelli, ${ }^{15}$ a state within the state.

As more and more possessions in the Levant and the Black Sea were dramatically lost to the advantage of the Ottomans, trade interests of Genoa and other naval and colonial empires were reoriented to the west. Corsica became more than ever a strategic bastion. For that reason, the hypothetical influence of Greek-Roman legal and administrative principles by rich émigrés, fled for the Ottomans, can be tested in this convenient case study.

By consequence, we must study the colonial experiment of the Banco di San Giorgio on the Isle in the context of a general westwards shift in the Mediterranean Sea, which eventually lead to the colonial expansion across the oceans. In other words: this big transition period from Middle Ages until Modern Times, symbolized by the year 1453, changed both the face of Corsica and Europe. ${ }^{16}$

\footnotetext{
${ }^{13}$ WisZNIEWSKI, Histoire de la banque de SaintGeorges.

${ }^{14}$ The Most Serene Republic of Genoa.

${ }^{15}$ MACHIAVELLI, Istorie fiorentine 8.

${ }^{16}$ Ibidem : "[...] la prise de Constantinople en 1453 par les turcs va ouvrir une nouvelle page d'histoire pour tout l'Occident."
} 
The financial model of the Banco was revolutionary for that time. Moreover, Giuseppe Felloni gave a plea for a rewriting of the financial history of Europe by seeing the Genoese inventions as the precursors of the Amsterdam Exchange Bank and the Bank of England, hundreds years later. ${ }^{17}$ With regard to the discussed colonial model 18 of the Banco one thing is sure: the less knowledge, the more controversy. What we know is that the organizational structure was very innovative in its election, function and revision of officials. It must be seen in the tradition of the Maonae, ${ }^{19}$ private consortia with a mercantalist policy, which did already exist under Genoese rule in Chios and Cyprus. ${ }^{20}$ One could expect that the novel egalitarian approach with an abstract bureaucratic rule would provoke conflicts in the feudal Corsican society which was built on personal contacts and contracts in close communities.

\section{From personal contract to social contract: the will of the popolo (1358-1453-1528)}

To fully understand these conflicts in the $15^{\text {th }}$ and $16^{\text {th }}$ century, we have to consider that the legal history of Corsica is dictated by warfare. After the sea battle of Meloria in 1284 (victory 1), the Genoese took the power in Corsica over from Pisa. It was the start for almost five centuries of dominance on the Isle. From a purely historical perspective, one could argue that the French influence was less important than the Genoese. In this whole period, the major opponent on the international scene was Aragon, who had their basis in Sardinia. Their defeat in 1346 (victory 2) caused an ever-lasting feudal

\footnotetext{
${ }^{17}$ FELLONI, Moneta, credito e banche 257.

${ }^{18}$ CANCELLIERI, Formes rurales 89.

${ }^{19}$ Petti BALBI, I maonesi e la maona (1378-1407).

20 See: Argenti, Occupation of Chios 271.
}

struggle between the Corsican nobility and the popolo. The insurrection of the latter in 1358 could be compared with the impact of the Jacquerie in France and lead to a division of the Isle which was determinant until today. The Terra del Comune (representative to the people) and the Terra dei Signori (representative to feudal landlords) can be identified as the two French departments Haute-Corse and Corse du Sud. What was now the will of the popolo?21 As the name Terra del Comune reveals, they wanted to be governed like the commune in Genoa in order to put an end to the feudal oppression by an equal and just administration. This colonial legal form of concession or deditio is called appalto. From now on things ought to be made legal through the hands of the Genoese. Not really surprising, the competing landlords in the Terra dei Signori reacted vehemently on this kind of social contract which infringed the personal hierarchy established by feudalism. Namely, their ultimate objective was the sovereign rule in the tradition of the counts of Corsica, like Arrigo della Rocca did or Vincentello d'Istria as a vice-king of the Aragonese crown.

As a result we see a clear division in Corsican society caused by politics: on the one hand a feudal structure reminding of the Middle Ages in the south and on the other hand the modernist idea of a political authority which respects and protects the rights and liberties of the local tradition. In 1453, both through internal conflict and external threat of warfare, this quarrel reached a climax, with the second call for help from the popolo. This time to the Banco di San Giorgio

${ }^{21}$ FRANZINI, Un peuple libre 11. 


\section{From political clientelism to procedural equality and back: a violent rollercoaster (1453-1562)}

Indeed, the dispute between an individual and a collective conception of political representation was reflected in the procedural reality of Corsica. A new social contract and legal ground for the rule of San Giorgio, the so-called Capituli Corsorum, ${ }^{22}$ expressed once again in 1453 the will of the popolo to end the revolutionary struggle with the seigneurs and the wish to be governed by a strong, modern and fair power. Evidently, what counted for a financial institution as the Banco di San Giorgio, were abstract rights, strict rules and an efficient administration. ${ }^{23}$ The private consortium with public powers represented the most modern idea of organization in that time. No kingdom, no principality, no papacy and no feudal tradition. In other words: the political, fiscal, military, ideological and economic transformations of San Giorgio could shape a procedural reality which could transcend the old dramatic divisions on the Isle. But unfortunately, the continuity of these feudal principles was another striking reality. A strong hierarchy created subordination and a system of alliances and adherence. The Statutes of San Colombano, in Cap Corse, form an example of a legal order with penal and civil law, which consist of vassali, partitanti and aderenti. These were no subjects of rights, but members of a feudal system in which the seigneur operated as a military and judicial guarantee of decisions taken by his vassals, who adhere voluntary in this organizational communities. These statutes show the reality of subjects who only exist by grace of recognition within an agricultural community. It is a type of alliance which is not anymore to be backed by Roman law, but is an expression of the High Middle

\footnotetext{
${ }^{22}$ Capitula corsorum.

${ }^{23}$ MOLARD, Documents inédits 74.
}

Ages with blood lineage and a familial community as founding marches of society.

\section{Conclusion}

So, I hope you understand how different the approach of the Banco di San Giorgio was and why the popolo looked in their direction to solve the seemingly ineradicable roots of clientelism. The procedural reality in Corsica was expressed by the organization of justice in micro regions, called the pieve, originally consisting of fled people in the mountains due to feudal struggle and who were reorganized and controlled by the Church. This lay the basis for a system of clientelism where the personal affiliation was primordial. The notion of parti, constituted by principles of allegiance, loyalty and solidarity in the name of justice, became one of the driving forces of Corsican political and legal thought. This dependence on the selfish seigneurs ultimately undermined confidence in the legal institutions, which could for example explain the appearance of vendetta in this close-tight communities. On the contrary, the Capitula Corsorum of 1453 meant a real first document in the administrative and political history of Corsica. With a real modern reasoning, there could not be a substantial and sustainable solution to the political problems, without a constitutional project. The republican dream of the popolo, dating already from 1358, seemed at last realized in 1528, when the Comune in Genoa faced the democratic transformation ${ }^{24}$ symbolized by the Constitution of Andrea Doria. The basic foundations $^{25}$ of the Republic of Genoa could now by reflected in a colonial social contract with the Terra di Comune in Corsica. Moreover, the Banco di San Giorgio introduced a kind of modern bureaucratic system with elected and paid officials

\footnotetext{
${ }^{24}$ COLES, Crisis of Renaissance Society 17.

25 SHAW, Counsel and Consent 834.
} 
and a system of checks and balances with the institution of the Syndicato. Yet, the eternal revival of the feudal seigneurs meant in the end a deficit of the colonial experiment. The Banco had to return to military power and brutal force as it seemed the only alternative to gain and keep control over the Isle. By doing so, the Genoese had become the seigneurs of Corsica themselves. ${ }^{26}$ At the heart of the democratic process there was an idea of political and legal selfdetermination by the popolo. The core value of the Corsicans was a desire of justice and a fair legal order. But the old dream of a system based on a republican spirit turned out to be idle.

Too bad, behind each procedural reality there lays a political reality. And that is the ultimate reality where the Corsicans are confronted with until today.

\section{Korrespondenz:}

Matthias Castelein

KU Leuven Kulak - Subfaculty of Law Etienne Sabbelaan 53, 8500 Kortrijk, Belgium Matthias.Castelein@kuleuven-kulak.be

\section{Literatur:}

Philip ARgENTI, The Occupation of Chios by the Genoese and Their Administration of the Island 13461566, in: The Journal of Modern History 32 (1960) 271-272.

Jean-Marie ARrighI, Olivier JeHASSE, Histoire de la Corse et des Corses (Paris 1998).

BBC News, Life for Corsica prefect murderer [http://news.bbc.co.uk/2/hi/europe/7143297.stm] (2007, retrieved on: 13. 5. 2012).

Jean-André CANCELLIERI, Formes rurales de la colonization génoise en Corse au XIIIe siècle: un essai de typologie', in: Mélanges de l'Ecole française de Rome, Moyen-Age, Temps Modernes 93 (1981) 89-146.

Capitula corsorum, in: Bulletin de la société des sciences. Historiques et naturelles de la Corse 1 (1881) $263 \mathrm{ff}$.

Mario Chiaudano, Giorgio Costamagna, L'archivio storico del Banco di San Giorgio di Genova (13861845), in: Archivi storici delle aziende di credito 1 (1956) 115-117.

Paul Coles, The Crisis of Renaissance Society Genoa 1488-1507, in: Past \& Present 11 (1957) 17-47

Emmanuelle DelaHAye, La Corse, la dernière colonie française? [http://www.cafe-geo.net/article.php3? id_article=562] (2005, retrieved on 12. 5. 2012).

Lisa D'OrAZIO, Une île de Violence: le traitement médiatique du « Problème corse » (1965-2007), in: Rives méditerranéennes, Jeunes chercheurs 35/36 (2010) 1-15.

Giuseppe FELLONI, Inventario dell'Archivio [http://www.lacasadisangiorgio.it] (2012, retrieved on: 12. 2. 2012).

Giuseppe Felloni, L'Archivio della Casa di San Giorgio di Genova (1407-1803) ed il suo ordinamento, in: Scritti di Storia Economica 1 (1984) 451-459.

Giuseppe FELLONI, Moneta, credito e banche in Europa: un millennio di storia (Genua 1997).

Antoine FRANZINI, Un peuple libre, sauvage et vertueux: nature et politique dans la Corse du Quattrocento, in: Médiévales 47 (2004) 2-12.

Francis MOLARD, Documents inédits sur l'histoire de la Corse. Dépêches des protecteurs de SaintGeorges à leurs fonctionnaires et à leurs partisans dans l'île de Corse (1454-1457), in: Bulletin historique et philologique 14 (1896) 1-74.

Giovanni PeTti BALBI, I maonesi e la maona di corsica (1378-1407): un esempio di aggregazione economica e sociale, in: Mélanges de l'Ecole française de Rome. Moyen-Age, Temps modernes 93 (1981) 147-170. 
Regional policy European Union, The airport for goats,

[http://ec.europa.eu/regional_policy/projects/storie s/details.cfm? pay $=$ FR\&the $=9 \&$ sto $=227 \&$ lan $=7 \&$ regi on=ALL\&obj=ALL\&per=ALL\&defL=DE]

(2011, retrieved on: 27. 4. 2012).

Antoine Laurent SERPENTINI, La criminalité de sang en Corse sous la domination génoise (fin XVIledébut XVIIIe siècles), in: Crime, Histoire \& Sociétés 7 (2003) 2-18.
Christine SHAW, Counsel and Consent in FifteenthCentury Genoa, in: The English Historical Review 116 (2001) 834-862.

Michel Verge-FrAnCHESI, La Corse enjeu géostratégique en Méditeranée et les marins Cap Corsins, in: Cahiers de la Méditerranée 70 (2005) 1-12.

Adam WisZNIEWSKI, Histoire de la banque de SaintGeorges de Gênes, la plus ancienne banque de l'Europe et des origines du Crédit Mobilier, du Crédit Foncier, des Tontines et des amortissements y pratiqués au moyen âge, (Paris 1865). 